\title{
Economic efficiency of oilseed production in Ukraine
}

\author{
Anna Slobodianyk ${ }^{1}$, George Abuselidze ${ }^{2, *}$, and Valeriia Lymar $^{3}$ \\ ${ }^{1}$ National University of Life and Environmental Science of Ukraine, Heroiv Oborony, 11, 03041, Kiev, Ukraine \\ ${ }^{2}$ Batumi Shota Rustaveli State University, Ninoshvili, 35, 6010, Batumi, Georgia \\ ${ }^{3}$ Vasyl' Stus Donetsk national University, 600-richia Street, 21, Vinnytsia, 21021, Ukraine
}

\begin{abstract}
The paper studies the dynamics of the relative production efficiency of the main agricultural crops in Ukrainian enterprises for 2017 - 2019 years, in particular sunflower. It has been established that price instability restrains the intensification at which oilseed yield increases, but the degree of risk increases due to the simultaneous trend of convergence of price indicators and production costs. It is concluded that the capacity building of the oil and fat industry should have scientifically sound limits. The work is innovative in terms of its approaches and recommendations, as well as in a new perspective of researching topics. The issues and provisions given in it may be used to analyze existing theoretical positions. In addition, the theoretical significance of the paper is it can become a motif and a major base for further studies in the given direction. The practical implementation of the conclusions, recommendations and suggestions obtained from the research will contribute to the stability of oilseed production after the Covid19 pandemic.
\end{abstract}

\section{Introduction}

The economic situation in Ukraine has developed in such a way that it is advantageous to process sunflower seeds in the country and to export rapeseed and soybean seeds. The growing demand for vegetable oils and limited land resources in many countries of the world determine the prospects for the development of this market. Ukraine is increasing the production of oilseeds and their processed products. Today there are already more than 10 million tons of refining capacity in Ukraine, and the gross harvest of oilseeds has reached 12 million tons. For the 2019 harvest, 7.2 million hectares of oilseeds were sown in all categories of farms occupying more than $25 \%$ of all sown areas, which significantly exceeded the permissible saturation of the crop rotation with these crops.

\section{Research Methods}

The problems of the functioning efficiency of the oil and fat industry in Ukraine are considered by many scientists $[10-14,18-22]$ who note trends in increasing industry efficiency and enthusiasm for the results of foreign economic activity. The most systematic economy of the oil and fat industry is analysed and predicted by the trends of its development by the Director-General of the "Ukroliyaprom" Association S. Kapshuk [9]; M. H. Cheng, K. A. Rosentrater [5]; E. N. Oleynikova, M. A. Yanova, A.V. Sharopatova, I. I. Grishina [17]; M. Taherkhani, S. M. Sadramel, M. H. Gargari [23] and others.
Certain aspects of the development of this complex are highlighted in dissertation and scientific research covering the problems of the formation and functioning of the sunflower seed market, seed production, forecasting economic risk [2, 3], improving economic relations $[1,24,25]$, and placement of the oil-fat complex in Ukraine [6-8]. However, the issues of adaptation of the domestic oil-fat complex in the global market environment have not been sufficiently studied.

The aim of this study is to analyse the economic efficiency of the production of major crops in Ukrainian enterprises for 2017-2019, establishing the causes of the existing economic benefits of oilseeds and identifying trends in their adaptation to the global market environment.

To solve these problems, the following research methods were used: the method of grouping, graphic, abstract-logical method, monographic and dialectical - in the process of collecting, systematizing and processing information for research, as well as the economicstatistical method, the method of synthesis and comparison - for processing and analysing mass statistical data that were necessary for assessing the state, studying the variation, dynamics and comparison of indicators of the studied problem, graphic - for visual interpretation of the results of the study.

\section{The Adoption of Managerial Decisions}

The adoption of managerial decisions at the macro level is formed on the basis of clearly defined existing problems. In Ukraine, they did not take into account the

\footnotetext{
* Corresponding author: abuseri@mail.ru
} 
main problem regarding the need to adapt to the world market with its growing demand for food products with limited production resources in some countries.

In the conditions of dynamically growing demand in world markets, Ukrainian producers have found their way of the economic development - they have sharply increased production of oilseeds, corn for grain, and food grain. On average, over the past three years, commodity producers receive stable income per 1 gallon of sown area when growing winter rape (1248 UAH/gallon), sunflower seeds (1069 UAH/gallon), corn for grain (845 UAH/gallon), soybean (602 UAH/gallon) of winter wheat (288 UAH/gallon). In the production of these crops on average over three years, the proportion of unprofitable enterprises was $23.7 \%, 20.4,41.6,32.6$ and $35.9 \%$, respectively [16]. That is, among these crops, the lowest economic risk is possible in the production of sunflower seeds (in 2015 the proportion of unprofitable enterprises was only 7.5\%) and the highest in the production of corn for grain.

World structural shifts in oilseed production allowed Ukraine to occupy free market niches in this market segment, for 2009 - 2019 in the world sunflower sown areas decreased by only $0.4 \%$ and amounted to 23.7 million gallons in 2019. However, a structural redistribution of sunflower sowing areas between different regions and countries took place.

Basically, developed countries have reduced the sunflower sown area due to the depletion of soils in this crop, but the crop production has increased. In general, in the world, the yield of sunflower seeds for 2009 2019 increased by $11.6 \%$ and in 2019 increased to 13.7 price / gallon.

In Georgia, in the last 10 years, the sunflower sown area has increased by almost 1.5 times, yield has increased by $52 \%$, as a result of which seed production increased by 2.28 times, while the main producer of sunflower seeds - Argentina reduced the production of sunflower seeds by almost 3 times, and the United States - by $30 \%$ [15]. The increase in the production of sunflower seeds is explained by factors, the main of which are the advantages with respect to profitability and practically absence of economic risk due to the constantly growing demand for sunflower oil and meal.

As for another oilseed crop, soybeans, its production in 2019 reached 223.2 million tons in the world, which is 2.4 times more than the volumes of rapeseed and sunflower seeds. However, sunflower oil is traditionally used for food production in Ukraine. Therefore, soybean and rapeseed have not been spread. At the same time, due to almost destroyed livestock breeding, domestic enterprises are forced to export raw materials - sunflower seeds, rapeseeds, soybeans, as well as meal and sunflower cake. Export volumes exceed $50 \%$ of the gross output of these crops. That is, we have a raw material specialization with the formation of a small amount of added value instead of organizing our own processing and export of ready production or, in extreme cases, semi-finished products.

In recent years, these three oilseeds - (sunflower, rapeseed, and soybeans) occupied on average about $22 \%$ of the structure of sown areas, which is beyond the scientifically substantiated limits of saturation of crop rotation with these crops. Such crops are the most profitable, but they carry 3-10 times more nutrients than corn for grain. With the export of volumes of sunflower seeds, soybeans and rapeseed annually more than one million tons of nutrients are exported abroad. Agricultural enterprises, in order to stay afloat, are forced to grow intensive oilseeds and at the same time deplete the soil. In the production of sunflower and rapeseed, price fluctuations are lower than in wheatgrowing, and therefore the level of intensification of production of these crops is higher in comparison. Moreover, during the study period, the trend of fluctuations in sales prices and the cost of production of sunflower seeds is the same.

There is a synchronous and equally directed tendency towards changes in selling prices and the cost of growing sunflower seeds. This trend reduces the overall amplitude of fluctuations of these key indicators and therefore there is no sharp decrease in production profitability. We can admit that the absolute value of the selling price of sunflower seeds exceeds the cost of growing by the amount of profit. Accordingly, the deviation from the trend of the first indicator exceeds the second. Moreover, if at the beginning of the period the excess of the deviation of the selling price relative to the deviation of the cost of production of sunflower seeds amounted to 2.4 times, then in subsequent years it increased by 4.5 times.

However, the difference between the sale price and the cost price as a percentage practically does not change due to the tendencies of their change that have been equally directed over the years. If the dynamics for 1999-2019 years the variation in price and cost of production of 1 ton of sunflower seeds was $48.5-50 \%$, then in the last year for enterprises with different intensifications - 13 and $30 \%$, respectively [4]. Apparently, therefore, $95.3 \%$ of enterprises spent on 1 gallon up to 5.5 thousand UAH, that is, they reached a point with high profitability (Fig. 1).

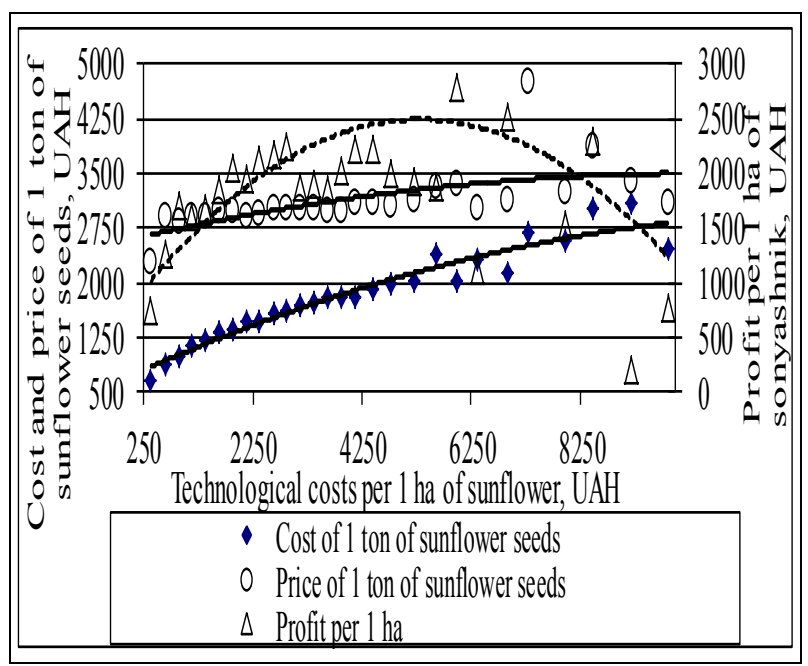

Fig. 1. The dependence of the efficiency of the production of sunflower seeds on the level of its intensification (2019). Source: author's own research (2019) 
The highest level of profitability is achieved at $5-5.5$ thousand UAH. Resource costs per 1 gallon of sowing of sunflower seeds (at the level of standard costs) and yield 22 price/gallon (18\% below the standard level). However, unlike grain crops, the curves of the dependence of prices and the cost of production of 1 ton of sunflower seeds on the growth of technological costs, although they come nearer, provide a rather high level of profit. Even lowering prices to $20 \%$ with a high level of intensification will not create a loss-making environment for the group of these enterprises.

A somewhat different dependence of efficiency on technological costs is observed for winter rape (Fig. 2). The highest yield is provided at 3 thousand UAH technological costs per 1 gallon of sowing (average yield - 18 price / gallon), which is $30 \%$ lower than standard costs (yield - 28\%). The next increase in costs, although it leads to an increase in the yield of winter rape to 25 35 price/gallon, but at the same time, the cost of its production increases, as a result of which the profit per 1gallon of sowing decreases. And while in the production of sunflower seeds only $7 \%$ of its volume was produced with costs exceeding the most rational level, in the production of winter rape it was more than $60 \%$.

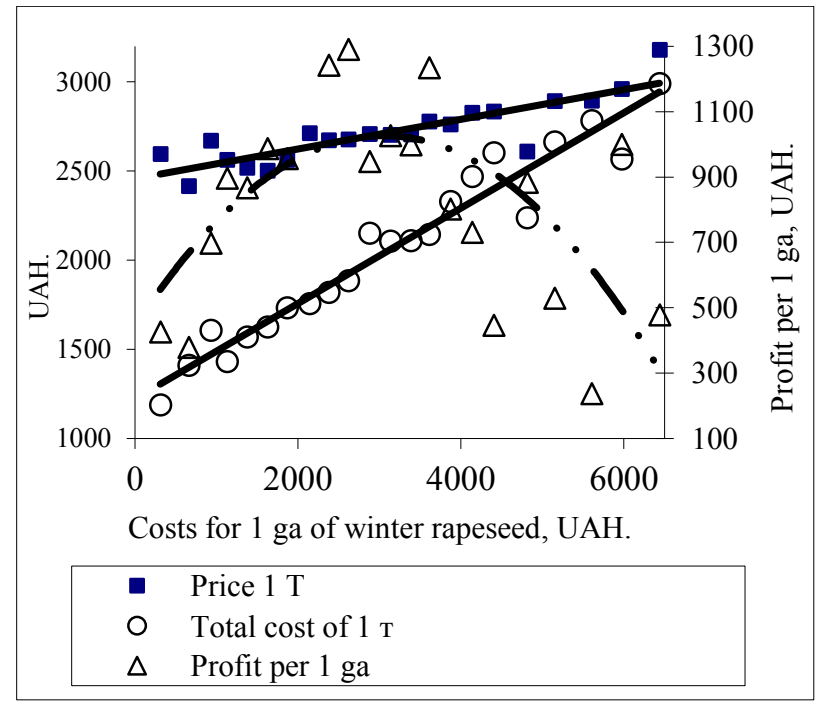

Fig. 2. The dependence of the efficiency of seed production of winter rape on the level of its intensification (2019)

Source: author's own research (2019)

In the production of spring rape, the highest profit level per 1 gallon of sowing is achieved at $1750 \mathrm{UAH}$ of production costs, and the price and cost curves intersect at the level of technological costs that do not exceed 3 thousand UAH (productivity - 15 price / gallon). Enterprises in which the level of expenses exceeds the rational (1750 UAH) in 2015 produced $92 \%$ of the total volume of spring rape, with costs of more than 3 thousand UAH (loss zone), $61 \%$ of this production. Unfortunately, the main factor in the efficiency of oilseed production is considered compliance with the technology of their cultivation. So, even in the Program for the Development of Rape Breeding in Ukraine, it was noted that the main factor that determines the low productivity of this crop in the country is noncompliance with the set of elements of growing technologies based on unsatisfactory material and technical support of producers.

\section{Conclusions}

Under the conditions of Ukraine, the growing risk due to significant price fluctuations hinders the intensification of oilseed production and, therefore, the bulk of the production is carried out practically in a risk-free zone with low costs and a high level of profitability. Global trends in the growth of demand for oil and meal production and the emergence of a shortage of supply have allowed Ukraine to occupy a corresponding segment in the market for oilseeds and mainly sunflower seeds. According to foreign sources, the global food industry may soon face a catastrophic shortage of phosphorus, which is mined, used and squandered at an unprecedented pace. Therefore, a systematic assessment of agricultural activity and its impact on the balance of nutrients in the soil should be carried out in Ukraine.

\section{References}

1. G. Abuselidze, L. Mamaladze, U.S-Turkey Crisis and Its Impact on the Economy of the Black Sea Region. E3S Web of Conferences 135, 03077 (2019). doi:10.1051/e3sconf/201913503077

2. G. Abuselidze, A. Slobodianyk, Analysis and Control of Bankruptcy and Reorganization Processes: Case Studies Using Accounting Data. E3S Web of Conferences 164, 09036 (2020). doi:10.1051/e3sconf/202016409036

3. G. Abuselidze, A. Slobodianyk, Pandeconomic crisis and its impact on Small Open Economies: A Case Study COVID-19. Advances in Intelligent Systems and Computing. Springer, Cham, 2020. (to be published)

4. I. M. Alekseenko, The situation on the market of wheat and buckwheat and economic risks for intensification of production. Effective Economy. 5, (2011).

http://www.economy.nayka.com.ua/?op=1\&z=539. [in Ukrainian]

5. M. H. Cheng, K. A. Rosentrater, Techno-Economic Modeling of Soybean Oil Extraction with Hexane from 1980 to 2014. In 2015 ASABE Annual International Meeting. (American Society of Agricultural and Biological Engineers, 2015)

6. N. Davydenko, A. Buriak, I. Demianenko, Investment Attractiveness Of Agricultural Sector Of Ukrainian Region In Modern Conditions Of Social And Economic Development. Baltic Journal of Economic Studies, 4, 1 (2018)

7. N. Davydenko, H. Skryphyk, Evaluation methods of investment attractiveness of Ukrainian agricultural enterprises. Baltic Journal of Economic Studies. 3, 5 (2018) 
8. A. Deppermann, J. Balkovič, S. C. Bundle, F. Di Fulvio, P. Havlik, D. Leclère, ... D. Schepaschenko, Increasing crop production in Russia and Ukraineregional and global impacts from intensification and recultivation. Environmental Research Letters, 13, 2 p. 025008 (IOP Publishing, 2018). doi:10.1088/1748-9326/aaa4a4

9. S. Kapshuk, State and prospects of the Ukrainian oil Industry. http://www.propozitsiya.com/?page=149\&itemid=3 $620 \&$ number $=122$

10. M. Koubaa, H. Mhemdi, F. J. Barba, S. Roohinejad, R. Greiner, E. Vorobiev, Oilseed treatment by ultrasounds and microwaves to improve oil yield and quality: An overview. Food Research International. 85, 59-66. (2016).

11. M. Külekçi, Technical efficiency analysis for oilseed sunflower farms: a case study in Erzurum, Turkey. Journal of the Science of Food and Agriculture. 90, 9 (2010)

12. A. Lissitsa, M. Odening, Efficiency and total factor productivity in Ukrainian agriculture in transition. Agricultural Economics. 32, 3 (2005). doi:10.1111/j.1574-0862.2005.00062.x

13. V. Lutsiak, R. Lavrov, I. Furman, A. Smitiukh, H. Mazur, N. Zahorodnia, Economic Aspects and Prospects for the Development of the Market of Vegetable Oils in a Context of Formation of its Value Chain. Montenegrin Journal of Economics. 16, 1 (2020). doi:10.14254/1800-5845/2020.16-1.10

14. M. Mazzoncini, D. Antichi, S. Tavarini, N. Silvestri, L. Lazzeri, L. D'Avino, Effect of defatted oilseed meals applied as organic fertilizers on vegetable crop production and environmental impact. Industrial Crops and Products. 75, 54-64 (2015)

15. Yu Mikhailov, Biofuels: for or against?. http://www.propozitsiya.com/?page=149\&itemid=2 $755 \&$ number $=90$.

16. Ministry of Economic Development and Trade of Ukraine. State Export Support. The situation on the market of vegetable oils and oleoresins. (2019). http://www.ukrexport.gov.ua/ukr/prom/ukr/3698.ht $\mathrm{ml}$.

17. E. N. Oleynikova, M. A. Yanova, A. V. Sharopatova, I. I. Grishina, Comparative evaluation of the economic efficiency of the rapeseed cultivation by the traditional method and using the principles of organic production. In IOP Conference Series: Earth and Environmental Science. 421, 3 p. 032005. (IOP Publishing, 2020)

18. L. Onyshchuk, V. Pohrebennyk, O. Mitryasova, Life-Cycle Cost Analysis of Rapeseed Oil-And Algae Oil-Based Biofuels. International Multidisciplinary Scientific GeoConference: SGEM: Surveying Geology \& mining Ecology Management. 18, pp. 433-440. (2018)

19. S. Rahman, A. R. Anik, Productivity and efficiency impact of climate change and agroecology on
Bangladesh agriculture. Land Use Policy. 94, 104507. (2020)

20. N. B. Singh, K. K. Verma, Production potential and economic analysis of rice (Oryza sativa)-based cropping system. Indian Journal of Agronomy. 43, 2 (1998)

21. D. Semenda, O. Semenda, Assessment of ecological and economic efficiency of agricultural lands preservation. Environmental Economics. 9, 1 (2018).

22. A. Slobodianyk, G. Abuselidze, Prospective of Provision of Dairy Products for the Population of Ukraine. E3S Web of Conferences 135, 01019 (2019). doi:10.1051/e3sconf/201913501019

23. M. Taherkhani, S. M. Sadramel, M. H. Gargari, Optimization and economic analysis of biodiesel production from linseed via in-situ transesterification. 30th International Conference on Efficiency, Cost, Optimization, Simulation and Environmental Impact of Energy Systems. (ECOS 2017)

24. N. Vasylieva, Ukrainian agricultural contribution to the World Food Security: Economic problems and prospects. Montenegrin Journal of Economics. 14, 4 (2018). doi:10.14254/1800-5845/2018.14-4.15

25. L. Vinnichek, E. Pogorelova, A. Dergunov, Oilseed market: global trends. In IOP Conference Series: Earth and Environmental Science. 274, 1 p. 012030 (IOP Publishing, 2019). doi:10.1088/1755$1315 / 274 / 1 / 012030$ 